\title{
CONSTITUTION OF DIFFERENT SIGNAL PEPTIDES FOR ENHANCED THERMOSTABLE ALPHA AMYLASE SECRETION IN Bacillus subtilis
}

\author{
Nguyen Thi Da, Nguyen Kim Thoa, Tran Dinh Man* \\ Institute of Biotechnology, VAST, 18 Hoang Quoc Viet, Cau Giay, Ha Noi \\ "Email: ntda@ibt.ac.vn
}

Received: 22 April 2017, Accepted for publication: 28 November 2017

\begin{abstract}
Three signal peptides of alpha amylase genes of three isolated strains: Bacillus licheniformis DA23, Bacillus subtilis D5-2, Bacillus cereus CN1-5 were successfully sequenced. Three predicted "Sec - type" signal peptides have a length varying from 27 (CN1-5) to 33 residues (D5-2). The secretion of alpha amylase of the recombination B. subtilis 168MPgrac strain (pHV33- $\mathrm{P}_{\text {grac }} \mathrm{Amy} 3 \mathrm{BT} 2$ ) with $71.4 \pm 6.3 \mathrm{U} / \mathrm{ml}$ and the ratio of $\alpha$ - amylase activities to total amount of protein secretion reached $38.05 \mathrm{U} / \mathrm{mg}$ was larger than that of 168MPamy with $53.2 \mathrm{U} / \mathrm{ml}$. Base on analyzed results of PAGE and zymogram about molecular weight, alpha amylases in both strains were the same size, nearly $58 \mathrm{kDa}$. Three signal peptides were constructed in recombinant pHV33 - Pgrac vectors. To further evaluate the efficiency of these SPs in B.subtilis, $\alpha$-amylase activity was measured. The extracellular amylase activity of signal peptide $S_{\text {subtilisD5.2 }}$ in $168 \mathrm{M}$ was the highest with $76.4 \pm 3.7 \mathrm{U} / \mathrm{ml}$ in four signal peptide targets. These results indicated that the promoter $\mathrm{P}_{\text {grac }}$ and signal peptide amylase gen $\mathrm{S}_{\text {subtilisD5.2 }}$ tested in this study might be used for secretion $\alpha$-amylase in B. subtilis $168 \mathrm{M}$.
\end{abstract}

Keywords: Bacillus, signal peptide, secretion, amylase, megaprimer.

Classification number: $1.2 .1 ; 1.3 .2 ; 3.7 .2$.

\section{INTRODUCTION}

Amylases are important hydrolase enzymes which have been widely used since many decades. Among the amylase family, $\alpha$ - amylase is an industrially important one because of the ubiquitous nature, easy of production and broad spectrum of applications. This enzyme has potential application in a wide number of industrial processes such as food, fermentation, textile, paper, detergent and pharmaceutical industries as representing approximately $30 \%$ of the world enzyme production [1]. This enzyme randomly cleaves $\alpha-1,4-$ internal glycosidic linkages in starch molecules to hydrolyze them to yield glucose, maltose, dextrins and oligosaccharides. $\alpha$ amylases can be obtained from animals, plants and microorganisms, especial enzyme from fungal and bacterial sources, have been focused upon and preferred to other sources for applications in industrial sectors [2,3].

For commercial applications $\alpha$-amylase is mainly derived from the genus Bacillus. It is estimated that Bacillus sp. enzymes make up about $50 \%$ of the total global enzyme market. 
These organisms not only produce an appropriate range of enzymes but also have the capacity to secrete them into the culture medium at high concentrations. Purification from the culture medium rather than from the cytoplasm considerably reduces downstream processing costs. In recent years, considerable effort has been aimed at developing $B$. subtilis as a host for the production of heterologous proteins. Bacillus genus is Gram-positive bacteria that secrete a large number of extracellular proteins of industrial relevance. B.subtilis, B.licheniformis, B.amyloliquefaciens, B.megaterium etc. are known to be good producers of $\alpha$-amylase [3, 4].

Most proteins are transported across the cytoplasmic membrane and secreted directly into growth medium of Gram positive bacteria. They are generally synthesized as precursors with a cleavable signal peptide, that is removed by signal peptidases during or shortly after translocation. The secretion of protein in Bacillus genus is synthesized by four pathways: Sec, Tat, Com and ABC transporter [5, 6]. Sec pathway is major secretion for approximately 300 proteins in Bacillus genus therefore called the general secretion pathway in this genus [7]. Signal peptide in Sec pathway usually is $18-40$ amino acids long and although the primary structures of different signal peptides show a little similarity and don't have sequence homologous, this signal always consists of three identifiable domains as: a positively charged amino terminal (N-), a central hydrophobic (H-), and carboxyl-terminal (C-) regions [7, 8]. $\mathrm{N}$ region is 1-5 amino acids long, charged positive, and often has two amino acids Lys and Arg [6,9]. The hydrophobic core (H region) with 7 - 15 amino acids takes an alpha helical conformation when it contacts with the membrane lipid phase. The $\mathrm{C}$ - terminal region is hydrophilic and contains the signal peptide cleavage site in the -1 and -3 positions of the signal peptide that is recognized with most of a consensus cleavage site Ala-X-Ala (71\%), V - X -A (18\%) [10]. Alpha amylase of Bacillus genus is secreted into growth medium by Sec pathway and then signal peptide is cleaved by Signal peptidase I.

\section{MATERIALS AND METHODS}

\subsection{Bacterial strains and media}

Table 1. The content of recombination in Megaprimer method construction.

\begin{tabular}{|c|c|c|c|c|c|}
\hline Strains & $\begin{array}{l}\text { Flank } \\
\text { Primer }\end{array}$ & $\begin{array}{l}\text { Target } \\
\text { gene } 1\end{array}$ & Recombinant constructs 1 & $\begin{array}{l}\text { Target } \\
\text { gene } 2\end{array}$ & Recombinant constructs 2 \\
\hline $\begin{array}{ll}\text { B. } & \text { subtilis } \\
\text { D5.2 } & \\
\end{array}$ & $\begin{array}{l}\text { DASub } \\
\text { Sig5.2 }\end{array}$ & \multirow{3}{*}{ 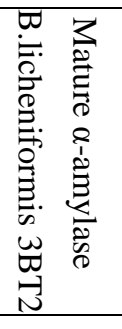 } & DASsub3BT2Mature & \multirow{4}{*}{ 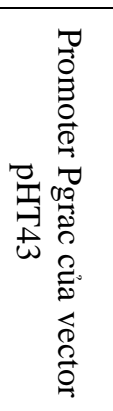 } & Pgrac-DASsub3BT2Mature \\
\hline \begin{tabular}{ll|}
$B$. & cereus \\
$\mathrm{CN} 15$ &
\end{tabular} & $\begin{array}{l}\text { DACer } \\
\text { Sig15 }\end{array}$ & & DAScere3BT2Mature & & Pgrac-DAScere3BT2Mature \\
\hline $\begin{array}{l}\text { B.licheniformis } \\
\text { DA23 }\end{array}$ & $\begin{array}{l}\text { DALich } \\
\text { sig23 }\end{array}$ & & DASliche3BT2Mature & & $\begin{array}{l}\text { Pgrac- } \\
\text { DASliche3BT2Mature }\end{array}$ \\
\hline $\begin{array}{l}\text { B.licheniformis } \\
\text { 3BT2 }\end{array}$ & & & DA3BT2full & & Pgrac-DA3BT2full \\
\hline
\end{tabular}

Table 1 shows the content of recombination in Megaprimer method construction. The collection of Bacillus sp. Strains was isolated from many soil samples in different regions in LB with $1 \%$ solution starch and bacterial strains were stored at $4{ }^{\circ} \mathrm{C}$ for entire study. E. coli JM109, 
E. coli DH5a, B. subtilis 168M in the collection strains of Biomaterial Lab were used to host strains.

\subsection{Additional substrates}

The additional substrates for screening bacteria are gathered in Table 2 .

Table 2. Additional substrates for screening bacteria in this study.

\begin{tabular}{cccc}
\hline Substrates & Dilute solutions & Stock concentrations & $\begin{array}{c}\text { Final } \\
\text { concentration }\end{array}$ \\
\hline Ampicillin & $\mathrm{H}_{2} \mathrm{O}$ deion & $50 \mathrm{mg} / 1 \mathrm{ml}$ & $60 \mu \mathrm{g} / \mathrm{ml}$ \\
Chloramphenicol & Ethanol $70 \%(\mathrm{v} / \mathrm{v})$ & $100 \mathrm{mg} / 1 \mathrm{ml}$ & $20 \mu \mathrm{g} / \mathrm{ml}$ \\
IPTG & $\mathrm{H}_{2} \mathrm{O}$ deion & $1 \mathrm{M}$ & \\
Xgal & Dimethylformamide & $20 \mathrm{mg} / \mathrm{ml}$ & $40 \mu \mathrm{g} / \mathrm{ml}$ \\
\hline
\end{tabular}

\subsection{DNA isolation and purification}

Total DNA of these strains was isolated mainly by Ausubel' method [11].

DNA plasmid isolation:

+ Isolation of plasmids from E. coli by Alkaline Lysis [12] and Thermo Scientific Plasmid DNA extraction kit (GeneJET miniprep kit).

+ DNA plasmid of Bacillus was isolated by Voskuil and Chambliss [13].

The DNA product from agarose gel was cut and purified by the GeneJET Gel extraction kit was supplied by the manufacturer.

\subsection{Primer sequences}

The primer sequences used in this study are presented in Table 3.

\subsection{Isolation of signal peptide sequences, target gene fragment by PCR method}

The study signal peptide sequences were extracted from strains by PCR method with primer sequences for signal peptide which were designed from original point of the interested $\alpha$ amylase gene and conservative region I of this gene based on the published sequences in NCBI (Table 3). Standard PCR method was used to amplify the target genes with reaction temperature under optimal conditions optimal for temperature of primers.

\subsection{Megaprimer}

Megaprimer method is based on polymerase chain reaction and utilizes "flank" primers with two rounds of PCR [14 - 16]. In this article, Megaprimer is the method used to join an interested signal peptide with the target gene and joins promoter with this recombinant construction. 
Table 3. Primer sequences in this study.

\begin{tabular}{|c|c|}
\hline Primers & Sequences 5 , $\rightarrow$ \\
\hline DABlisigaF & ATGAAACAACAMAAACGGCTT \\
\hline DABlisigaR & GTGGTTGATGACYACATCCCC \\
\hline DABsusigaF & ATGTTTAMAAAACGATTCAAAAC \\
\hline DABsusigaR & GTATGATTGATRACCGCTC \\
\hline DABcesigaF & ATGTTTAAAAAAGTAACAATAG \\
\hline DABcesigaR & TTATGATTCATAACTACATC \\
\hline PribaliRsig-SacII & AGCGTCCCATTAAGACTTGCCCGCGGCGCCGCTGCTGACAGAATGA \\
\hline PribasuRsig-SacII & AGCGTCCCATTAAGACTTGCCCGCGGAGCGTTTGCAGCCGCCGGG \\
\hline PribaceRsig-SacII & AGCGTCCCATTAAGACTTGCCCGCGGGTGCATATGCTTTACTCCC \\
\hline Pri2BaliMatur3bt2 & GCAAGTCTTAATGGGACGCTGA \\
\hline P3BL-XbaI & TTAA $\underline{T C T A G A C A A A G A A A T T T T A T A A G A A G}$ \\
\hline P3BL - EcoRI: & GAGGAAGAATTCCAAAGAAATTTTATAAGA \\
\hline $\begin{array}{l}\text { FprimerPgrac - EcoRI- } \\
\text { KpnI }\end{array}$ & GGCC $\underline{G A A T T C T T A G C T T G G T A C C A G C T A T T G}$ \\
\hline RPgrac $=3^{\prime}$ XhoI & TCAT $\underline{C T C G A G T T C C T C C T T T A A T T G G G A ~}$ \\
\hline $\mathrm{F}_{3 \mathrm{BT} 2 \mathrm{mature}}-\mathrm{SacII}$ : & GCT $\underline{C C G C G G G C A A G T C T T A A T G G G A}$ \\
\hline DABsusigaF XhoI & GAGGAA $\underline{C T C G A G A T G T T T A A A A A A C G A T T C A}$ \\
\hline DABcesigaF - XhoI & GAGGAACTCGAGATGTTTAAAAAAGTAACA \\
\hline DABlisigaF - Xhol & GAGGAA $\underline{C T C G A G A T G A A A C A A C A A A A A C G}$ \\
\hline FgraclinkerSig & CCCAATTAAAGGAGGAA $\underline{C T C G A G A T G T T T A A A}$ \\
\hline
\end{tabular}

\subsection{SDS-PAGE}

The SDS polyacrylamide gel electrophoresis was performed according to [22] and these proteins are stained silver by the Holtzhauer's protocols [17].

\subsection{Results analysis}

The result of DNA sequences were analyzed by Serial cloner programs, MEGA 5.0, BioEdit, Chromas, DNADynamo, SigmaPlot, etc. and DNA data are available online at websites [23].

\section{RESULTS}

In this study, three signal peptides were screened by recombination to integrate the target genes and assessed the ability to increase $\alpha$-amylase secretion. The host used for this study was B. subtilis $168 \mathrm{M}$. The target gene carried on a common object is the mature segment of the $\alpha-$ amylase strain 3BT2 after the cutoff of SPaseI in the Sec pathway. The experimental purpose was mapped in Figure 1. 


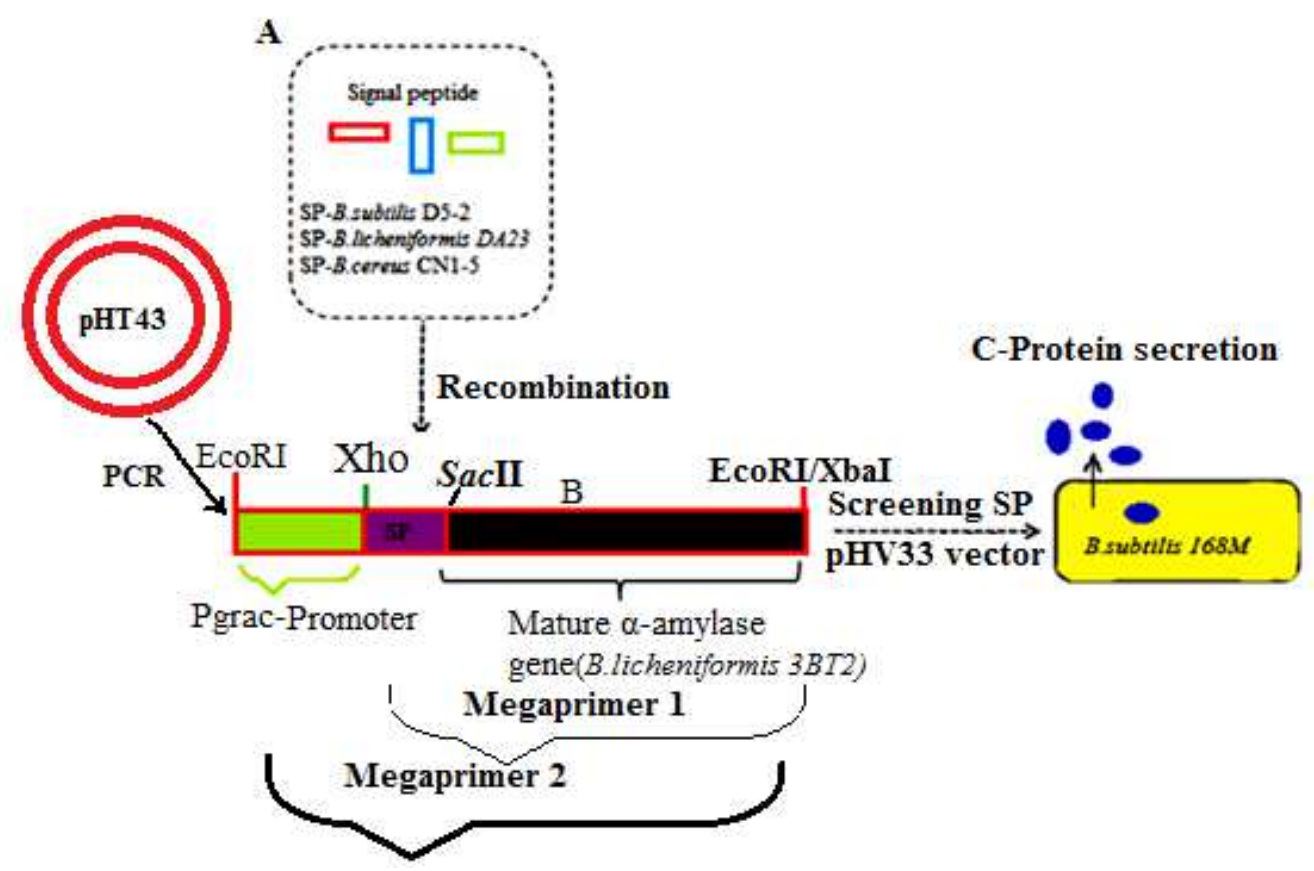

Figure 1. The diagram of the strategy to increase the ability of $\alpha$-amylase secretion in $168 \mathrm{M}$ ' host cells (A), three SPs isolated from B. subtilis, B. licheniformis and B. cereus by PCR methods. (B), and the mature $\alpha$-amylase of strain 3BT2 used as the target protein (C). Bacillus $168 \mathrm{M}$ was used to screen signal peptide libraries and this strain was used to evaluate the level of secretion of recombinant $\alpha$-amylase.

\subsection{Construction of recombinant Pgrac - SPs - amylase mature gene by Megaprimer method and conjunction with pHV33 vector for screening of amylase activity expression in E. coli}

There are many methods to improve secretion of alpha amylase activity, but method that used in this report is replaced by signal peptide of wild alpha amylase of by isolated signal peptide alpha amylase genes from three Bacillus strains. Because most exported proteins are transported through the Sec pathway in B. subtilis, three different Sec-type signal peptides of 3 alpha amylase genes (Signal peptide of gene alpha amylase of B. subtilis D5-2 ( $\mathrm{S}_{\text {subtilisD5.2), } B \text {. }}$ cereus $\mathrm{CN} 1-5\left(\mathrm{~S}_{\text {cereusCN15}}\right)$, B. licheniformis DA23 ( $\mathrm{S}_{\text {licheniformisDA23 }}$ ) were cloned and fused to the $\alpha$ amylase gene of $B$. licheniformis 3BT2 (lacking its native signal peptide) by megaprimer method (Figure 2) that exhibit high secretion efficiency in B. subtilis pHV33-Pgrac-3BT2Amyfull (pHVAmy3BT2). Four recombinant construction vectors: pHVAmy3BT2, pHV33-Pgrac-

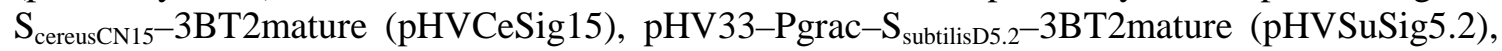
pHV33-Pgrac $-\mathrm{S}_{\text {licheniformisDA23 }}$-3BT2mature (pHVLiSig23) were transformed in B. subtilis $168 \mathrm{M}$ to form four strains as 168MSubsig52, 168MCeSig15, 168MLisig23, 168M3BT2. These strains could efficiently secrete proteins into the culture medium. Secretion of target gene in recombinant strains was estimated by total protein, activity of $\alpha$-amylase and protein electrophoresis. 


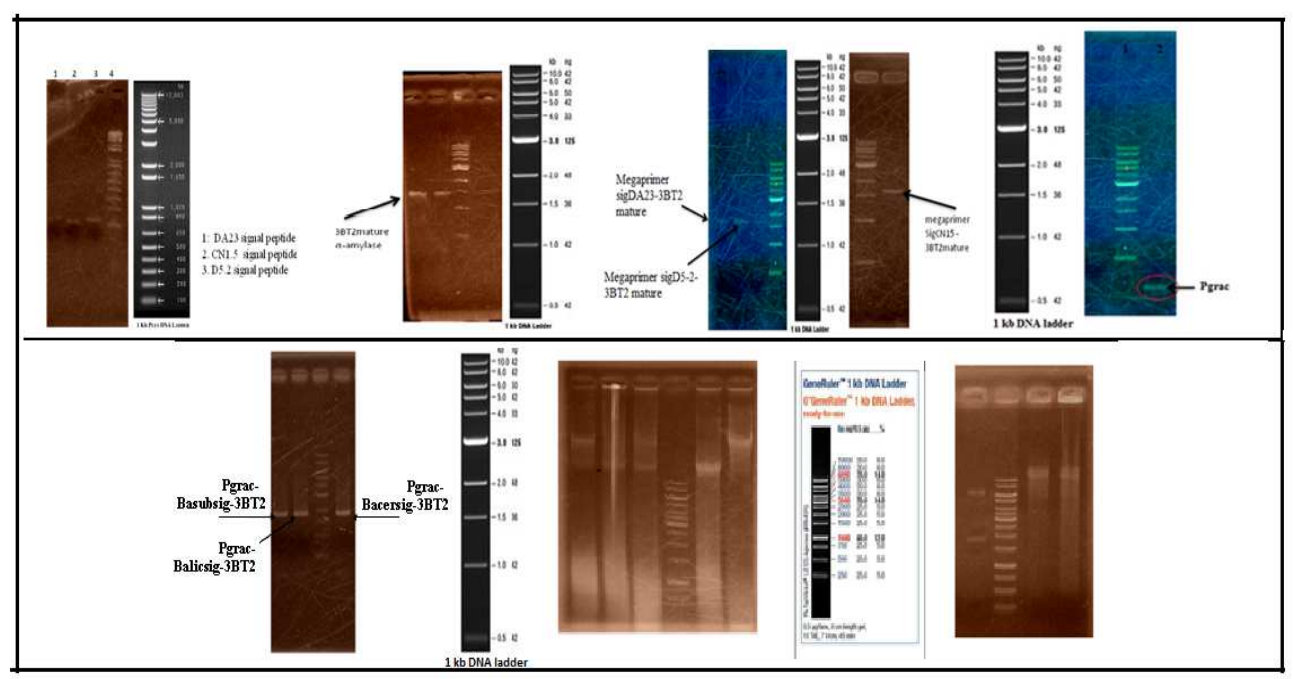

Figure 2. Construction of system to fuse target genes by Megaprimer method.

\subsection{Effect of two promoters on amylase expression and secretion}

The thermophilic $\alpha$-amylase from $B$. licheniformis $3 \mathrm{BT} 2$ possessed unique traits that made it a great potential candidate for use in the industry. However, this train produced only small amounts of $\alpha$-amylase. To solve these problems, the $\alpha$-amylase gene was cloned and expressed in B. subtilis $168 \mathrm{M}$, which is an ideal food-grade host for heterologous protein expression. The promoters Pgrac and $\mathrm{P}_{A m y}$ were used to construct 2 different expression vectors for testing to secrete high levels of this $\alpha$-amylase with initial pHV33 vector to express in $B$. subtilis $168 \mathrm{M}$.

Table 4. The expression and secretion of recombinant amylase in B. subtilis 168M.

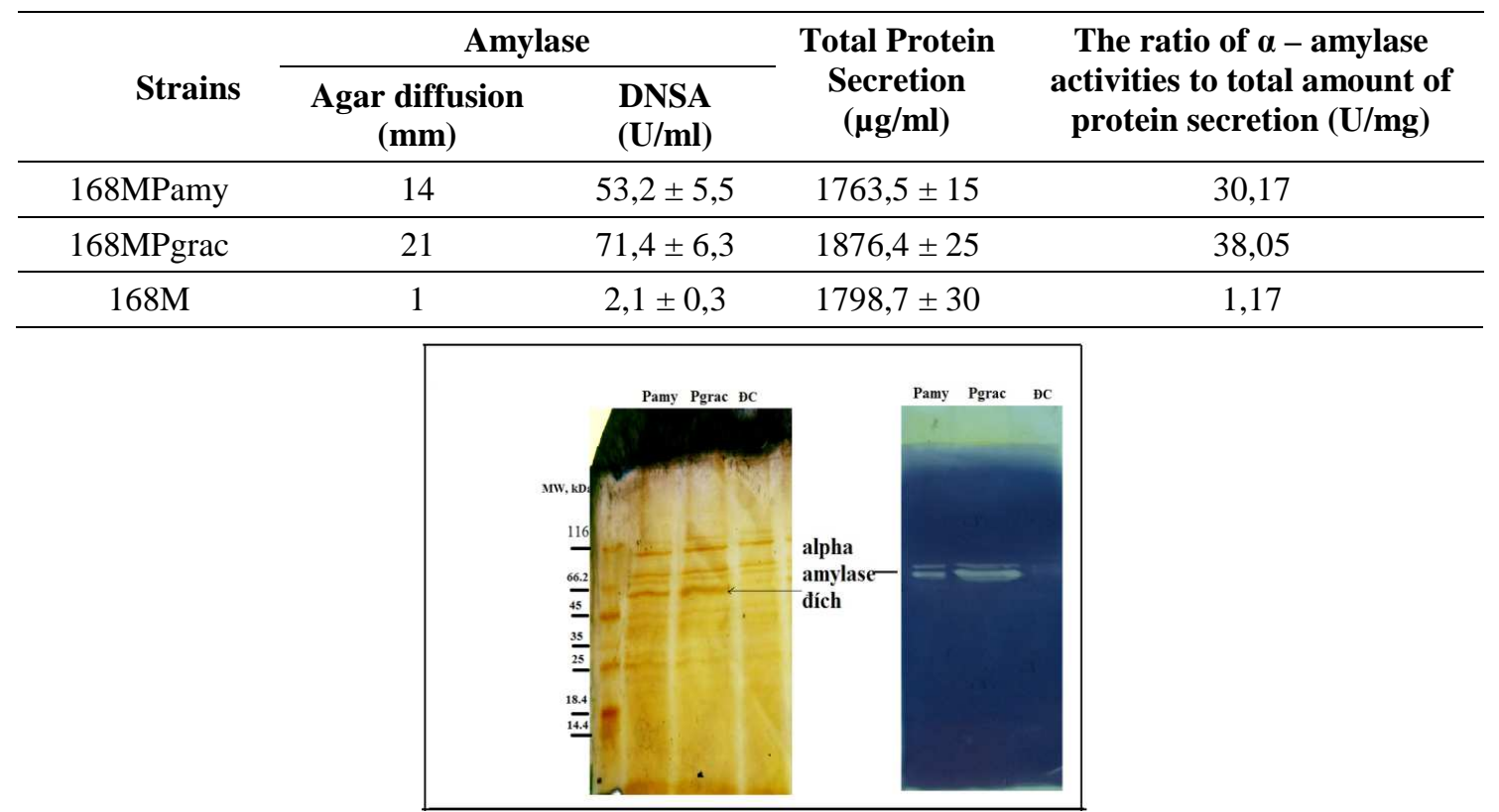

Figure 1. Effect of promoter on amylase secretion of recombinant strains. 
The results in Table 4 and Figure 3 showed that secretion efficiency of the constructed pHV33 vector with promoter Pgrac was higher than that of the vector with promoter Pamy. To compare the activity alpha amylase of the recombination B. subtilis 168MPgrac strain (pHV33$\mathrm{P}_{\text {grac }}$ Amy3BT2) and B. subtilis 168MPamy strain (pHV33- $\mathrm{P}_{\text {amy }}$ Amy3BT2, recombinant vector construction of pHV33 containing the Pamy promoter of B. subtilis $168 \mathrm{M}$ and alpha amylase gene of $B$. licheniformis 3BT2 was noticed a little activity of $53.2 \mathrm{U} / \mathrm{ml}$ after $36 \mathrm{~h}$. It was less 1.3 fold than activity of the recombination strain containing gene cluster of Pgrac promoter and target gene $(71.4 \mathrm{U} / \mathrm{ml})$ at the same time. These results indicated that, Pgrac promoter in this study might be useful for the expression and secretion of target gene in B. subtilis and so it was chosen for further research. Zymogram analysis and amylase activity of two recombination trains showed that the crude extracts of alpha amylase by ethanol were analyzed by PAGE. The alpha amylase was clearly detected in both strains with the same molecular weight nearly 58 $\mathrm{kDa}$. Ying et al. expressed high levels of the hyperthermophilic $\alpha$-amylase from Thermococcus sp. HJ21 in B. subtilis, the promoters $\mathrm{P}$ grac , P xylA, P43, and $\mathrm{P}$ hag were used to construct four different expression vectors for testing [18].

\subsection{Evaluation of expression efficiency of alpha amylase of recombinant constructors in B. subtilis 168M}

To determine the expression efficiency of the four SPs on the amylase secretion, for plasmid pHV33-Pgrac-3BT2Amyfull (pHVAmy3BT2), pHV33 - Pgrac - $\mathrm{S}_{\text {cereusCN15 }}$ -

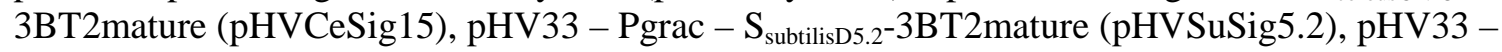
Pgrac $-S_{\text {licheniformisDA23 }}$-3BT2mature (pHVLiSig23) were transformed in B. subtilis $168 \mathrm{M}$. These recombinant strains were named as 168M3BT2, 168MCeSig15, 168MSubsig52, 168MLisig23, respectively.

Table 5. Effect of different SPs on $\alpha$-amylase expression and secretion.

\begin{tabular}{|c|c|c|c|c|c|}
\hline \multirow[b]{2}{*}{ Strains } & \multicolumn{3}{|c|}{$\alpha-$ amylase activities (U/ml) } & \multirow[b]{2}{*}{$\begin{array}{c}\text { Total Protein } \\
\text { Secretion } \\
(\mathrm{mg} / \mathrm{ml})\end{array}$} & \multirow{2}{*}{$\begin{array}{c}\text { The ratio of } \alpha \\
\text { - amylase } \\
\text { activities to } \\
\text { total amount } \\
\text { of protein } \\
\text { secretion } \\
\text { (U/mg) }\end{array}$} \\
\hline & $\begin{array}{c}\text { Agar } \\
\text { diffusion } \\
(\mathbf{m m})\end{array}$ & $\begin{array}{c}\text { Cell } \\
\text { extraction }\end{array}$ & $\begin{array}{l}\text { Liquid } \\
\text { culture }\end{array}$ & & \\
\hline 168MSubsig52 & $23 \pm 1.5$ & $3.1 \pm 0.3$ & $76.4 \pm 3.7$ & $1896.4 \pm 35.0$ & $40.9 \pm 3.13$ \\
\hline 168MCeSig15 & $16.5 \pm 2$ & $4.9 \pm 0.7$ & $47.7 . \pm 4.6$ & $1767.2 \pm 21.6$ & $26.9 \pm 2.23$ \\
\hline 168MLisig23 & $21 \pm 1.5$ & $6.3 \pm 0.6$ & $71.3 . \pm 3.2$ & $1824.7 \pm 27.1$ & $38.7 \pm 0.72$ \\
\hline 168M3BT2 & $20.5 \pm 2$ & $4.1 \pm 0.4$ & $68.6 \pm 5.1$ & $1787.3 \pm 20.2$ & $37.5 \pm 1.42$ \\
\hline
\end{tabular}

The results in Figure 4 and Table 5 showed that efficiency expression of alpha amylase of four signal peptides was dissimilarity among these strains. The extracellular amylase activity of signal peptide $S_{\text {subtilisD5.2 }}$ in recombinant $168 \mathrm{MSubsig} 52$ was highest with $76.4 \pm 4.3 \mathrm{U} / \mathrm{ml}$ and that of signal peptide $S_{a m y ~ C N 1-5}$ in 168MCeSig15 was lowest in four strains with $47.7 \pm 4.6 \mathrm{U} / \mathrm{ml}$. The secretion efficiency of 168MSubsig52, 168MCeSig15 and 168Mlisig23 containing three signal peptides $S_{a m y ~ D 5-2}, S_{a m y ~ D A 23}$ and $S_{a m y ~ C N 1-5}$ were approximately $112 \%, 104 \%$ and $70 \%$ alpha amylase activity of $168 \mathrm{M} 3 \mathrm{BT} 2$, respectively. The optimal signal peptide $\mathrm{S}_{\text {subtilisD5.2 }}$ was 
used for further experiment. SPs play a very important role in the transport of secretion proteins by the Sec pathway because they interact with SecA proteins, the signal recognition particle (SRP) and they have recognized site for signal peptidases [5]. The interaction between SP and mature protein is also known to affect the secretion of proteins [5, 9]. Therefore, an effective signal peptide for the secretion of any target protein is the most important choice. Several reports were done for identifying effective signal sequences [19]. In the same species, the secretion efficiency of proteins with different signal peptides was different effects and the secretion process may be affected by these SPs [20,21].

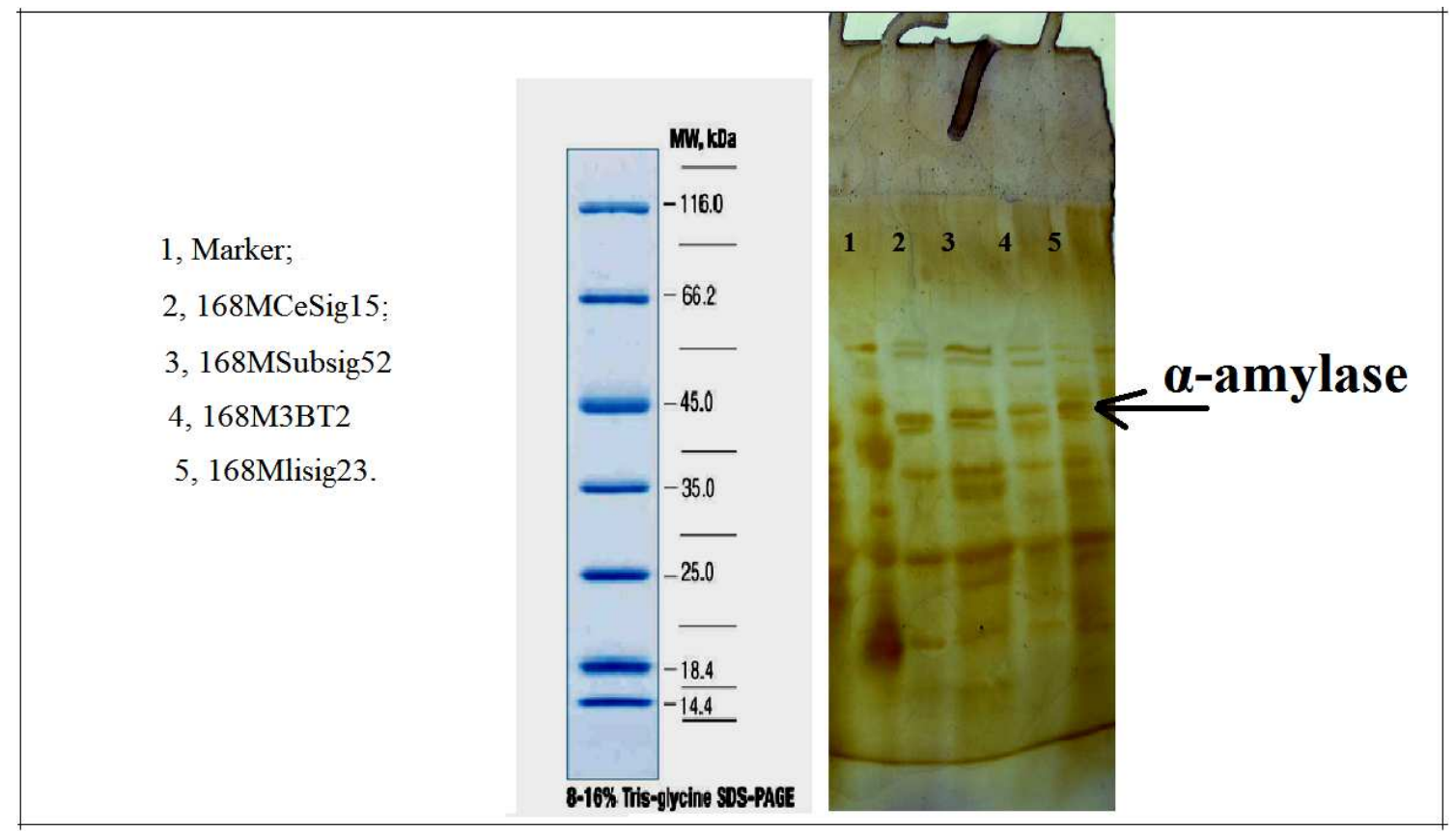

Figure 2. Effect of different SPs on alpha amylase secretion.

\section{CONCLUSION}

In this study, the effect of replacement SP alpha amylase of B.licheniformis 3BT2 on secretion one in $B$. subtilis was investigated by removing the SPs alpha amylase gene of other species in the same genus of Bacillus as B. cereus, B. subtilis, B. licheniformis. Four recombinant target genes transformed in B.subtilis $168 \mathrm{M}$ to evaluate for effect on the expression of amylase activity and secretion of protein of pHV33-Pgrac-3BT2Amyfull (pHVAmy3BT2), pHV33 - Pgrac $-\mathrm{S}_{\text {cereusCN15 }}$ - 3BT2mature (pHVCeSig15), pHV33 - Pgrac $-\mathrm{S}_{\text {subtilisD5.2- }}$

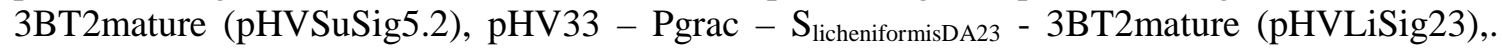
The results showed that the vector containing the alpha amylase SP of B. subtilis 168 and Pgrac promoter was found to have the highest transcriptional activity and produce the highest amylase activity.

Acknowledgment. This work was realized with the financial support from the Ministry of Industry \& Trade under the grant "Research on the production of recombinant heat-stable amylase enzyme for textile industry" Code: CBI / 2010-5. 


\section{REFERENCES}

1. Kiro Mojsov - Microbial $\alpha$-amylase and their inductrial applycations: A review. Int. J. Manag. IT Eng. 2 (2012) 583-609.

2. Zhang Q., Han Y., Xiao H. - Microbial $\alpha$-amylase: A biomolecular overview, Process Biochem. 53 (2017) 88-101.

3. Ray R. R. - Microbial Avicelase: an Overview, Bull. Env. Pharmacol. Life Sci. 4 (2015) 3-13.

4. Mobini-dehkordi M., Javan F. A. - Review Article: Application of alpha-amylase in biotechnology, J. Biol. today's world. 1 (2012) 39-50.

5. Harwood C. R., Cranenburgh R. - Bacillus protein secretion: an unfolding story, Trends Microbiol. 16 (2008) 73-79.

6. Leite K. C. - Construction of an efficient secretion system for recombinant proteins in Bacillus subtilis, Doktors der Naturwissenschaften. Universität Bayreuth, 2011.

7. Tjalsma H., Bolhuis A., Jongbloed J. D., Bron S., van Dijl J. M. - Signal peptidedependent protein transport in Bacillus subtilis: a genome-based survey of the secretome, Microbiol. Mol. Biol. Rev. 64 (2000) 515-547.

8. Pechsrichuang P., Songsiriritthigul C., Haltrich D., Roytrakul S., Namvijtr P., Bonaparte N., Yamabhai M. - OmpA signal peptide leads to heterogenous secretion of B. subtilis chitosanase enzyme from E. coli expression system, Springerplus 5 (2016) 1200-1210.

9. Low K. O., Mahadi N. M., Illias R. M. - Optimisation of signal peptide for recombinant protein secretion in bacterial hosts, Appl. Microbiol. Biotechnol. 97 (2013) 3811-3826.

10. Tjalsma H., Bolhuis A., Jongbloed J. D. H., Van Dijl J. M. - Signal Peptide-Dependent Protein Transport in Bacillus subtilis: a Genome-Based Survey of the Secretome, Microbiol. Mol. Biol. Rev. 64 (2000) 515-547.

11. Ausubel F. M., Brent R., Kingston R. E., Moore D. D., Seidman J. G., Smith J. A., Struhl K., Wiley C. J., Allison R. D., Bittner M., Blackshaw S. - Current Protocols in Molecular Biology, Vol. 1, 2003.

12. Sambrook J., Russell D. W. - Molecular cloning: a laboratory manual, Cold Spring Harbor Laboratory Press: Cold Spring Harbor, 2001.

13. Voskuil M. I., Chambliss G. H. - Plasmid DNA from Bacillus subtilis, Rapid Isolation and Sequencing of Purified Plasmid DNA from Bacillus subtilis, Appl. Environ. Microbiol. 59 (1993) 1138-1142.

14. Priyadharshini R., Manoharan S., Hemalatha D., Gunasekaran P. - Repeated random mutagenesis of $\alpha$-amylase from Bacillus licheniformis for improved $\mathrm{pH}$ performance, J. Microbiol. Biotechnol. 20 (2010) 1696-1701.

15. Liu H., Naismith J. H. - An efficient one-step site-directed deletion, insertion, single and multiple-site plasmid mutagenesis protocol, BMC Biotechnol. 8 (2008) 91-101.

16. Sambrook J., Russell D. W. - Rapid and Efficient Site-directed Mutagenesis by the Single-tube Megaprimer PCR Method, Cold Spring Harb. Protoc., 2006, pdb.prot3467.

17. Holtzhauer M. - Basic Methods for the Biochemical Lab., Springer Lab Manuals, First., Springer-Verlag BerlinHeidelberg, 2006. 
18. Ying Q., Zhang C., Guo F., Wang S., Bie X., Lu F., Lu Z. - Secreted expression of a hyperthermophilic $\alpha$-amylase gene from Thermococcus sp. HJ21 in Bacillus subtilis, J. Mol. Microbiol. Biotechnol. 22 (2012) 392-398.

19. Brockmeier U., Wendorff M., Eggert T. - Versatile expression and secretion vectors for Bacillus subtilis, Curr. Microbiol. 52 (2006) 143-148.

20. Fan X., Yang M., Cao P., Zhang W., Zhang W., Song X., Gong Y. - Screening of optimal signal peptide for heterologous xylanase secretion by Bacillus subtilis, Wei Sheng Wu Xue Bao 51 (2011) 979-983.

21. Heng C., Chen Z., Du L., Lu F. - Expression and secretion of an acid-stable alpha-amylase gene in Bacillus subtilis by SacB promoter and signal peptide, Biotechnol. Lett. 27 (2005) 1731-1737.

22. Laemmli U. K. - Cleavage of structural proteins during the assembly of the head of bacteriophage T4, Nature 227 (1970) 680-685.

23. http://www.ncbi.nlm.nih.gov; http://web.expasy.org/; http://www.ebi.ac.uk/clustalw/, www.cbs.dtu.dk/services/SignalP/(SignalP). 